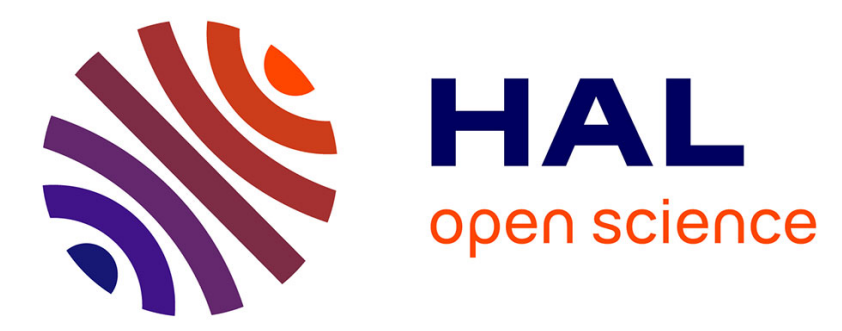

\title{
Crohn's disease during etanercept therapy in juvenile idiopathic arthritis: a case report and review of the literature
}

\author{
V. Wiegering, H. Morbach, A. Dick, H. J. Girschick
}

\section{- To cite this version:}

V. Wiegering, H. Morbach, A. Dick, H. J. Girschick. Crohn's disease during etanercept therapy in juvenile idiopathic arthritis: a case report and review of the literature. Rheumatology International, 2009, 30 (6), pp.801-804. 10.1007/s00296-009-0991-7 . hal-00568295

\section{HAL Id: hal-00568295 \\ https://hal.science/hal-00568295}

Submitted on 23 Feb 2011

HAL is a multi-disciplinary open access archive for the deposit and dissemination of scientific research documents, whether they are published or not. The documents may come from teaching and research institutions in France or abroad, or from public or private research centers.
L'archive ouverte pluridisciplinaire HAL, est destinée au dépôt et à la diffusion de documents scientifiques de niveau recherche, publiés ou non, émanant des établissements d'enseignement et de recherche français ou étrangers, des laboratoires publics ou privés. 


\section{Crohn`s disease during etanercept therapy in juvenile idiopathic arthritis}

\section{- A case report and review of the literature}

V. Wiegering, H. Morbach, A. Dick and H. J. Girschick

Wiegering_V@kinderklinik.uni-wuerzburg.de

Morbach_H@kinderklinik.uni-wuerzburg.de

dick_a@kinderklinik.uni-wuerzburg.de

Hermann.Girschick@mail.uni-wuerzburg.de

Pediatric Rheumatology, Immunology, Gastroenterology and Infectious Diseases, Children's

Hospital, University of Würzburg

Germany

Keywords:

juvenile idiopathic arthritis

etanercept

Crohn's disase

chronic inflammatory bowel disease

Correspond to: Prof. Dr. H. J. Girschick

Pediatric Rheumatology, Immunology and Infectious Diseases

Children's Hospital, University of Würzburg

Josef-Schneider-Str. 2

97080 Würzburg

Girschick_h@kinderklinik.uni-wuerzburg.de 


\begin{abstract}
Tumor necrosis factor alpha (TNFa) has broad effects in the immune system including lymphoid organ development as well as growth, survival und function of immune cells. TNFa has two main functions: regulatory effects and proinflammatory activities. In several diseases like juvenile and adult "rheumatoid" arthritis, psoriasis and chronic inflammatory bowel disease the application of TNFa blocking medications has been beneficial. However, induction of inflammation in several organs including the eye, the CNS, the skin and the gastrointestinal tract has been reported.

We report an eleven-year-old girl with juvenile idiopathic arthritis (JIA), who developed Crohn's disease (CD) while taking etanercept for her arthritis. Etanercept was discontinued and an antibody-based anti-TNF treatment using adalimumab was started, which induced remission of the gastrointestinal symptoms promptly. This case indicates that immunodysregulatory and even proinflammatory effects of etanercept are of relevance in the clinical practise. Furthermore, TNFa in part of its function seams to down regulate mucosal inflammation in CD.
\end{abstract}




\section{Introduction}

Tumor necrosis factor alpha (TNFa) has broad effects in the immune system including lymphoid organ development as well as the growth, survival und function of immune cells [1]. Two main functions of TNFa, regulatory effects and proinflammatory activities, are known. The pathogenesis of several autoimmune diseases including rheumatoid arthritis, JIA, psoriatic arthritis and Crohn's disease (CD) has been linked to an elevated TNFa expression at the site of inflammation [2]. However, due to the complex function of TNFa, immunodysregulation and even proinflammation has been reported. Patients treated with TNFa antagonists can develop several diseases including autoimmune or autoinflammatory conditions like systemic lupus erythematodes, uveitis, encephalomyelitis, glomerulonephritis, sarcoidosis, other granulomatous lesions and chronic inflammatory bowel disease $[3,4]$. Thus, TNFa blockade has to be monitored in this regard.

We report on an eleven-year-old girl with juvenile idiopathic arthritis (JIA), who developed Crohn's disease (CD) while taking etanercept for her arthritis. Etanercept is a fusion protein consisting of the extracellular portion of the human tumor necrosis factor alpha receptor linked to the Fc portion of human IgG. In particular, etanercept treatment has been associated with the induction of $\mathrm{CD}$ in adults and occasionally also in children and adolescents $[3,4]$. 


\section{Case Report}

A caucasian eleven-year-old, otherwise healthy girl had developed rheumatoid factor negative juvenile idiopathic polyarthritis (JIA) at the age of seven. The family history was not indicative, especially no history of autoimmune diseases or intestinal disorders. At the time of JIA diagnosis antinuclear antibodies were positive (titer 1:320), rheumatoid factors (IgM, IgA and $\mathrm{IgG}$ ) were negative. Arthritis involved elbows, hands and fingers, both ankles and some toes. There was no ophthalmologic involvement, especially no iridocyclitis. Treatment with non-steroidal anti-inflammatory drugs, glucocorticoids and methotrexate (MTX) was started effectively; however, the patient did not reach complete remission. Three years later the patient developed MTX related side effects including vomiting, abdominal pain and she refused to take MTX. Therefore medication was changed to TNFa-blockade using etanercept (weekly subcutaneous dose $0.8 \mathrm{mg} / \mathrm{kg}$ ). A complete remission of JIA was achieved. Thus, glucocorticoid treatment was reduced from $245 \mathrm{mg}$ prednisone/week $(1.1 \mathrm{mg} / \mathrm{kg} /$ day $)$ to 2.5 $\mathrm{mg} /$ week. NSAID medication (naproxen) was discontinued.

However, one year after etanercept therapy had been started the patient developed intestinal symptoms with massive bloody diarrhoea and abdominal pain. No infectious agents were detected. Chronic intestinal inflammatory disease was suspected and an endoscopy was performed. The colonoscopy showed ulceration and mucosal swelling of the terminal ileum, coecum and proximal colon. No stenosis was seen. A gastroduodenoscopy was normal. The diagnosis of Crohn's disease was confirmed by histology. Epitheloid granulomas were present. At that time autoantibody titres were repeated: a change in the profile was found: ANA were now negative $(<1: 80)$, whereas, $\mathrm{c}$ - and $\mathrm{x}$-ANCA were positive (titre 1:5120) and rheumatoid factors remained negative. Furthermore, we determined the HLA-B27 status, which was negative. NOD 2 / CARD15 (nucleotide oligomerization domain; caspase activation and recruitment domain) gene single nucleotide variants were examined and a single heterozygous R702W (Exon 4) mutation was found.

Since intestinal problems started during etanercept therapy we decided to discontinue this drug and to start a therapy with sulfasalazine $(50 \mathrm{mg} / \mathrm{kg} /$ day) as well as a nutritional therapy (modulen® diet; Nestle Inc., Lausanne, Switzerland). Unfortunately, bowel symptoms did not improve significantly and she newly developed ankle pain and arthritis. We decided to again start a TNFa-blocking medication targeting both the joint and gastrointestinal symptoms. Antibody based TNF-blocking medications have not been associated with the induction of chronic inflammatory bowel disease. Thus, we decided to introduce adalimumab. Of note, since the girl had not tolerated MTX comedication in the past, infliximab was not considered 
as an alternative, since MTX comedication is necessary to reduce induction of anti-infliximab antibodies. Under adalimumab therapy a clinical remission of intestinal and articular disease has been achieved rapidly and consistently. Nine months later the patient is still in remission. 


\section{Discussion}

We report an eleven-year-old girl who developed CD during etanercept therapy for JIA.

There are only a few reports on the development of chronic inflammatory intestinal diseases associated with etanercept therapy. Most of the described patients were diagnosed with ankylosing spondylitis or psoriatic arthritis $[2,5,6]$. These patients are known to have a higher risk for developing chronic inflammatory bowel disease whereas patients with JIA are not predisposed for developing $\mathrm{CD}$, except adolescents affected by enthesitis related arthritis or psoriatic arthritis. In these latter groups of patients it would be hard to differ whether CD is a side effect or coincidentally appearing.

There are several large follow up studies about the safety and effectiveness of etanercept in JIA, which could show that a significant proportion of patients improved joint affection during therapy $[3,4,7]$. Serious adverse events including gastrointestinal disease, sarcoidosis, sepsis, tuberculosis and malignancy were low (Incidence of severe adverse events 0.029 per patient year in total) $[3,4,7]$.

There is one report on a boy with oligoarticular, ANA positive, rheumatoid factor negative JIA and CD [8]. However, this patient had already developed intestinal symptoms before etanercept therapy and symptoms aggravated during etanercept. The patient went into remission of JIA and CD by infliximab treatment. Our patient had been free of symptoms consistent with CED before and during the first year of etanercept treatment.

Etanercept, infliximab and adalimumab appear to be comparably effective in treating signs and symptoms attributed to musculoskeletal inflammation including arthritis, tendinitis, sacroiliitis and spondylitis $[3,4,7]$. However, with respect to inflammation of the gut, the antiTNFa antibodies infliximab and adalimumab have been effectively controlling disease, whereas etanercept has shown to be ineffective [9]. The different binding patterns of TNFa and the biological action related to the antibody structure may explain the distinct biological effects of these anti-TNFa drugs. A further hypothesis is that neutralization of soluble TNFa by etanercept may result in a counter regulatory increase of cytokines, partly because T-cells themselves remain "unaffected" by etanercept [3,4,7]. Increased counter regulatory production of cytokines upon etanercept therapy may contribute to the onset of CD $[5,6]$. Furthermore, studies demonstrate that monoclonal anti-TNFa antibodies induced apoptosis of activated peripheral blood lymphocytes and lamina propria T-cells by directly binding to their surface $[10,11]$. 
Sfikakis et al. suggested that under certain circumstances, TNFa blocking agents may promote the activation of autoreactive T-cells, leading to tissue damage via autoimmune effector mechanisms. This scenario can lead to the induction of ANA antibodies and a SLE-like syndrome, predominantly observed with infliximab and the occurrence of other inflammatory diseases including uveitis, $\mathrm{CD}$ and cerebral demyelination particularly during therapy with etanercept [12] [13] [14]. Of interest, we found a change of the autoantibody profile in our patient after one year of etanercept therapy. We could not find a comparable case with a documented induction of c-/x-ANCA-autoantibodies, however, the induction of anti-doublestranded-DNA- antibodies has been described $[15,16]$.

It is documented that blockade of TNFa by etanercept can enhance T-cell production of IFN gamma (IFNg) and TNFa [2,6]. It is known that in genetically susceptible individuals increased levels of IFNg and TNFa in the intestinal mucosa can trigger inflammatory bowel disease [17]. Individuals with recently described NOD2 / CARD15 gene variants may be at risk for this side effect [17]. A similar effect on the cytokine production of T-cells present in the central nervous system may explain the increased frequency of inflammatory neurological complications [14,18]. In this regard, we looked at NOD2 / CARD15 gene variants in our patient and found a mutation at R702W. This mutation is found in approximately $4-5 \%$ of the healthy population and in over $10 \%$ of patients with particular autoimmune diseases, especially in CD [17,19]. Whether this mutation is disease relevant in our patient is unclear, but it might be a predisposition for CD. We did not analyze mucosal T-cell activation in our patient during etanercept therapy, but TNFa production in the sera of this patient was tested. We found elevated TNFa ELISA values before and during treatment with etanercept (TNFa in serum at diagnosis of polyarthritis $99.8 \mathrm{pg} / \mathrm{ml}$ (normal below $8.1 \mathrm{pg} / \mathrm{ml}$ serum), after 3 months of etanercept treatment $152 \mathrm{pg} / \mathrm{ml}$ ). At diagnosis of CD, TNFa levels increased to $418 \mathrm{pg} / \mathrm{ml}$. In the future it would be interesting to analyse mucosal TNFa production.

Since TNFa is believed to play a key role in the pathogenesis of CD [20] and TNFa antibodies have been used successfully for management of paediatric CD [8-10,21], we therefore discussed to switch therapy. There are two possibilities: Infliximab or adalimumab.

Because of former MTX intolerance in our patient adalimumab was preferred [22]. In contrast to infliximab, adalimumab contains only human amino acid sequences. Thus, it is thought to be less immunogenic than infliximab [23]. Until now only limited experience exists with respect to adalimumab treatment in childhood. There is a study reporting 14 children with CD treated with adalimumab: $50 \%$ of these patients showed complete remission after a mean of 5 
injections, 36\% did not improve. The most frequent side effects were nausea and vomiting. No severe side effects have been described [23].

Lovell and colleagues presented the 2-year safety and efficacy data of adalimumab treatment of juvenile rheumatoid arthritis in 171 patients. Serious side effects included neutropenia, herpes virus infection and pneumonia. No malignancies, tuberculosis or death occurred [24]. However, recent studies showed an increased risk of lymphoma in adults taking adalimumab, particularly in conjunction with azathioprine [25].

Until now, our patient showed no side effect and stable clinical remission of both gut and joint disease was noted after nine months of therapy. 


\section{References}

1. Beutler BA (1999) The role of tumor necrosis factor in health and disease. J Rheumatol Suppl 57:16-21 Medline.

2. Oh J, Arkfeld DG, Horwitz DA (2005) Development of crohn's disease in a patient taking etanercept. J Rheumatol 32:752-753 Medline.

3. Horneff G, De Bock F, Foeldvari I et al. (2008) Safety and efficacy of combination of etanercept and methotrexate compared to treatment with etanercept only in patients with juvenile idiopathic arthritis (jia). Preliminary data from the german jia registry. Ann Rheum Dis epublished

4. Prince FH, Twilt M, Ten Cate R et al. (2008) Long-term follow-up on effectiveness and safety of etanercept in jia: The dutch national register. Ann Rheum Dis epublished

5. Song IH, Appel H, Haibel H, et al (2008) New onset of crohn's disease during treatment of active ankylosing spondylitis with etanercept. J Rheumatol 35:532-536 Medline.

6. Zou J, Rudwaleit M, Brandt J, et al (2003) Up regulation of the production of tumour necrosis factor alpha and interferon gamma by $\mathrm{t}$ cells in ankylosing spondylitis during treatment with etanercept. Ann Rheum Dis 62:561-564 Medline. doi:10.1136/ard.62.6.561

7. Gerloni V, Pontikaki I, Gattinara M, et al (2008) Focus on adverse events of tumour necrosis factor alpha blockade in juvenile idiopathic arthritis in an open monocentric longterm prospective study of 163 patients. Ann Rheum Dis 67:1145-1152 Medline. doi:10.1136/ard.2007.069484

8. Ruemmele FM, Prieur AM, Talbotec C, et al (2004) Development of crohn disease during anti-tnf-alpha therapy in a child with juvenile idiopathic arthritis. J Pediatr Gastroenterol Nutr 39:203-206 Medline. doi:10.1097/00005176-200408000-00016

9. Sandborn WJ, Rutgeerts P, Enns R, et al (2007) Adalimumab induction therapy for crohn disease previously treated with infliximab: A randomized trial. Ann Intern Med 146:829838 Medline.

10. Lugering A, Schmidt M, Lugering N, et al (2001) Infliximab induces apoptosis in monocytes from patients with chronic active crohn's disease by using a caspase-dependent pathway. Gastroenterology 121:1145-1157 Medline. doi:10.1053/gast.2001.28702

11. Van den Brande JM, Braat H, van den Brink GR, et al (2003) Infliximab but not etanercept induces apoptosis in lamina propria t-lymphocytes from patients with crohn's disease. Gastroenterology 124:1774-1785 Medline. doi:10.1016/S0016-5085(03)00382-2

12. Sfikakis PP, Iliopoulos A, Elezoglou A, et al (2005) Psoriasis induced by anti-tumor necrosis factor therapy: A paradoxical adverse reaction. Arthritis Rheum 52:2513-2518 Medline. doi:10.1002/art.21233

13. Kunzmann S, Warmuth-Metz M, Girschick HJ (2005) Cerebral demyelination in association with tnf-inhibition therapy in a 5-year-old girl with aseptic meningitis as the first symptom of still's disease. Scand J Rheumatol 34:76-78 Medline. doi:10.1080/03009740510017887

14. Mohan N, Edwards ET, Cupps TR, et al (2001) Demyelination occurring during antitumor necrosis factor alpha therapy for inflammatory arthritides. Arthritis Rheum 44:2862-2869 Medline. doi:10.1002/1529-0131(200112)44:12<2862::AIDART474>3.0.CO;2-W 
15. Charles PJ, Smeenk RJ, De Jong J, et al (2000) Assessment of antibodies to doublestranded DNA induced in rheumatoid arthritis patients following treatment with infliximab, a monoclonal antibody to tumor necrosis factor alpha: Findings in open-label and randomized placebo-controlled trials. Arthritis Rheum 43:2383-2390 Medline. doi:10.1002/1529-0131(200011)43:11<2383::AID-ANR2>3.0.CO;2-D

16. Sfikakis PP, Kollias G (2003) Tumor necrosis factor biology in experimental and clinical arthritis. Curr Opin Rheumatol 15:380-386 Medline. doi:10.1097/00002281-200307000$\underline{00003}$

17. Russell RK, Wilson DC, Satsangi J (2004) Unravelling the complex genetics of inflammatory bowel disease. Arch Dis Child 89:598-603 Medline. doi:10.1136/adc.2003.041046

18. Suryaprasad AG, Prindiville T (2003) The biology of tnf blockade. Autoimmun Rev 2:346-357 Medline. doi:10.1016/S1568-9972(03)00048-X

19. Cavanaugh J (2006) Nod2: Ethnic and geographic differences. World J Gastroenterol 12:3673-3677 Medline.

20. Neurath MF, Fuss I, Pasparakis M, et al (1997) Predominant pathogenic role of tumor necrosis factor in experimental colitis in mice. Eur J Immunol 27:1743-1750 Medline. doi:10.1002/eji.1830270722

21. de Ridder L, Benninga MA, Taminiau JA, et al (2006) Infliximab as first-line therapy in severe pediatric crohn disease. J Pediatr Gastroenterol Nutr 43:388-390 Medline. doi:10.1097/01.mpg.0000226369.31956.bf

22. Hyrich KL, Symmons DP, Watson KD, et al (2006) Comparison of the response to infliximab or etanercept monotherapy with the response to cotherapy with methotrexate or another disease-modifying antirheumatic drug in patients with rheumatoid arthritis: Results from the british society for rheumatology biologics register. Arthritis Rheum 54:1786-1794 Medline. doi:10.1002/art.21830

23. Wyneski MJ, Green A, Kay M, et al (2008) Safety and efficacy of adalimumab in pediatric patients with crohn disease. J Pediatr Gastroenterol Nutr 47:19-25 Medline.

24. Lovell DJ, Ruperto N, Goodman S, et al (2008) Adalimumab with or without methotrexate in juvenile rheumatoid arthritis. N Engl J Med 359:810-820 Medline. doi:10.1056/NEJMoa0706290

25. Bongartz T, Sutton AJ, Sweeting MJ, et al (2006) Anti-tnf antibody therapy in rheumatoid arthritis and the risk of serious infections and malignancies: Systematic review and metaanalysis of rare harmful effects in randomized controlled trials. JAMA 295:2275-2285 Medline. doi:10.1001/jama.295.19.2275 